\title{
TRANSFORMATION TO SUSTAINABLE AND RESILIENT URBAN FUTURES IN SOUTHEAST ASIA
}

\author{
F. Lord ${ }^{1 *}$ \\ ${ }^{1}$ Institute for Sustainable Futures, University of Technology Sydney, 15 Broadway Ultimo NSW, Australia, 2007 - \\ Fiona.lord@uts.edu.au
}

\begin{abstract}
Commission IV
KEY WORDS: urbanisation, resilience, transformations, sustainable city, Cambodia, Vietnam, urban governance, sustainability
\end{abstract}

\begin{abstract}
:
The fast pace of urbanisation in Southeast Asia has undermined the sustainability of the social, economic and environmental infrastructure of many cities across the region. Urban resilience in Southeast Asian cities is being further impacted by the COVID-19 pandemic and climate change. While cities and national governments across the region have developed policies, strategies and programs to re-orient their cities towards more sustainable and resilient development pathways, many cities continue to struggle with the uncontrolled nature of urban development and compounding impacts of crisis events. This article provides an overview of major trends and challenges with urbanisation in Southeast Asia, focusing in particular on Cambodia and Vietnam, as well as the regional, national and sub-national policies and strategies established to address these trends and challenges. Given the current policy implementation gaps and ongoing challenges of urbanisation in Cambodia and Vietnam, the article makes the case for trans-disciplinary research to understand the potential for strengthening urban governance capacities for urban sustainability transformations.
\end{abstract}

\section{INTRODUCTION}

Urbanisation has reshaped cities around the world over the last three decades, particularly in the developing countries of Asia. Southeast Asia's urban populations have grown faster than the global average since 1990 (United Nations Department of Economic and Social Affairs [UN-DESA], 2018). In 2018, Southeast Asia's urban population reached 320 million out of a total of 655 million, or around 49 per cent of the region's population (UN-DESA, 2018). Southeast Asia's population is projected to increase to 730 million people by 2030 (Arfanuzzaman \& Dahiya, 2019), with the majority of population growth occurring in secondary cities (Dahiya, 2014).

While urbanisation has contributed substantially to economic growth, it has also driven increased resources consumption and pollution. Cities are the source of 75 per cent of global natural resources consumption and are responsible for 60 to 80 per cent of global greenhouse gas emissions (United Nations Economic and Social Commission of the Asia-Pacific [UN-ESCAP], 2017). Rapid urbanisation has also resulted in rising inequality and reduced the liveability of cities of many cities, particularly for the poorest and most vulnerable. Urbanisation is one of the biggest social transformations of modern times, having profound impacts on the environment manifest at local, regional and global scales (Bai et al., 2017). The challenges associated with rapid urbanisation in Southeast Asia require urgent attention, as the window of opportunity to switch to a sustainable model of urban growth is fast closing (Organisation for Economic Cooperation and Development [OECD], 2016b).

This article focuses analysis on Cambodia and Vietnam as two countries in Southeast Asia that are facing similar challenges with urbanisation, urban resilience and urban sustainability, although they are at different stages of economic development. Cambodia is a lower middle-income country and remains relatively un-urbanised with around 24.2 per cent of the population living in urban areas in 2020 . However, Cambodia's urban population growth rate is amongst the highest in the region at an average annual urban growth rate of 3.25 per cent over 2015 to 2020 (UN-DESA, 2018). Vietnam is a middle-income country and has experienced a rapid urban transition since the mid-1980s with its urban population estimated at 37.3 per cent in 2020 , and an average annual urban growth rate of 2.98 per cent over 2015 to 2020 (UN-DESA, 2018).

This article aims to answer the questions of 'what are the key sustainability and resilience challenges and pressures in the cities of Cambodia and Vietnam?' and 'how have governments sought to address these challenges and pressures through regional, national and sub-national policies and strategies?', based on the literature. The article then builds a case for trans-disciplinary research on the potential for urban sustainability transformations in Cambodia and Vietnam to address the urban challenges and pressures identified, and in particular, to investigate capacity strengthening for urban governance. There remains a lack of empirical research on urban sustainability transformations outside of developed countries (Koch et al., 2018), and limited research on the question of what enables cities and urban stakeholders to purposefully initiate and perform sustainability transitions and build capacity to prepare for and facilitate societal transformation processes (Wolfram, 2016; Wolfram et al., 2019). To address this research gap, the article outlines a research agenda to investigate urban transformations in a changing Southeast Asian context.

Sustainability in this context relates to global political discourse around sustainable development, defined by the World Commission on Environment and Development (1987) as "humankind has the ability to make development sustainable - to ensure that it meets the needs of the present without compromising the ability of future generations to meet their own needs". This definition was elaborated at the World Summit on Sustainable Development (2002), as "collective responsibility to advance and strengthen the interdependent and mutually reinforcing pillars of sustainable development - economic development, social development, and environmental protection - at local, national, regional and global levels". Sustainable cities are therefore urban systems that provide economic and social

* Corresponding author 
development, as well as environmental protection across scales, and without compromising the needs of future generations.

Sustainability and resilience are complementary and related agendas. Urban development requires the integration of both sustainability and resilience objectives if cities are to prosper, including integrated policies and plans towards inclusion, resource efficiency, mitigation and adaptation to climate change and resilience to disasters (Daudey \& Matsumoto, 2017; Grafakos et al., 2016). Resilience refers to the ability of a system, community, or society that is exposed to hazards to resist, absorb, accommodate and recover from the effects of a hazard in a timely and efficient manner (Grafakos et al., 2016). Resilience theory builds on the notion that humans are ultimately dependent on healthy ecosystems for their well-being (Olsson et al., 2014). Resilience also refers to the ability to maintain the capacity for adaptation, learning and transformation (Daniere \& Garschagen, 2019). A cities' resilience can be strengthened in order to protect the characteristics of an urban system (Grafakos et al., 2016).

Vulnerability can be understood as the coping capacity, in terms of the strengths and resources available within an exposed element to take action that mitigates or reduces the level of harm, loss or damage experienced by a hazard event (Daniere \& Garschagen, 2019). Urban vulnerability is the level of coping capacity of urban residents and urban systems to various hazards, events and exposures felt in the city.

\section{URBANISATION AND ASSOCIATED SUSTAINABILITY AND RESILIENCE CHALLENGES}

Rapid urbanisation has occurred in parallel with other significant trends in Southeast Asia, impacting the sustainability and resilience of the region's cities and the vulnerability of their residents. The following sections summarise the significant trends and associated sustainability and resilience challenges in Southeast Asian cities, particularly Cambodia and Vietnam, as identified in the literature. The trends discussed and their associated challenges are often consistent with the trends in other rapidly urbanising developing countries across the Asia-Pacific region (Sitko \& Goudswaard, 2019; UN-ESCAP \& UN-Habitat, 2019) and Africa (UN-Habitat, 2016), while their policy and strategy responses discussed are unique to each country. To understand the relevance of these concepts in current phases of urbanisation, we first need to understand the historical context of urbanisation policies and urban development.

\subsection{Rapid and uncontrolled urban development}

Urban growth has not been carefully planned or managed in many cities of Southeast Asia. Urban development has primarily been market-led and has often been chaotic or un-ordered (Dahiya, 2014; World Bank, 2018; Zhu, 2012). Long-term urban plans have in many cases failed in Southeast Asia, even if they have been aided by planning tools such as zoning codes, because they have not effectively responded to the dynamic political economy and socio-cultural processes that determine city growth (Dahiya, 2014). Most city-level spatial development plans in Southeast Asian urban agglomerations are not formally adopted as legally binding documents and are mainly regarded as "indicative guidelines" (OECD, 2016b). As a result, urban landscapes have been shaped by private investments in major urban development projects, including skyscrapers, satellite cities, special economic zones, hotels, condominiums and casinos.
The urban real estate boom in Southeast Asia is largely servicing international markets and the urban elite, rather than meeting local housing demands. An estimated 80 million people live in informal settlements in Southeast Asian cities (Dahiya, 2014). Tenure insecurity has become a significant threat to populations in informal settlements in Southeast Asia (Minnery et al., 2013). Urban poor communities without tenure security are at risk of being relocated to peri-urban areas due to major construction projects. Settlements in peri-urban areas often have less access to basic services, employment opportunities, and are often in more hazardous locations (Flower et al., 2018). The market-driven development of new settlements in Southeast Asian cities risks the creation of a form of social and spatial residential segregation (Spencer, 2010).

In Cambodia, the implementation of urban planning laws and policies is at an early stage. Cambodia's National Spatial Planning Policy (2011) established a tiered system for land-use planning, however very few spatial plans for cities have been formally adopted. The city of Battambang is an exception, with its Land Use Plan being approved in 2015. On the other hand, the capital city of Phnom Penh's Master Plan 2005-2020 has been discussed since 2002 but not yet adopted. In a strategic review of urbanisation in Cambodia, the World Bank (2018) noted "in practice there is relatively little urban planning which has left many cities unable to keep pace with urban expansion and resulted in a haphazard pattern of urban expansion." An influx of Foreign Direct Investment has resulted in a construction boom in cities such as Phnom Penh and Sihanoukville. With no land-use plan to guide this construction boom in these cities, the cityscape has changed dramatically, with high-rise developments replacing the low to medium-rise urban environment (World Bank, 2018).

Urban population growth has out-paced urban planning in Vietnam, although Vietnam has a complex legal and regulatory system to manage urban development. The level and capacity of urban management in Vietnam is low compared to the requirements (Chu \& Nguyen, 2017). While Vietnam has longterm masterplans in place for its major cities, these masterplans have not always been enforced. In Hanoi, for example, none of the Master Plans $(1998,2003,2008)$ have been fully implemented (Leducq \& Scarwell, 2018). Huynh (2015) argues that urban planning has been misused in Ho Chi Minh City, as urban planning has in practice provided a 'facilitator vehicle' to enable the municipality to negotiate with the central government and the private sector, rather than for the public good. Market liberalisation since the mid-1980s has led to great speculation in real estate markets (Ngo, 2015) and pent-up (and volatile) rises in land values in cities such as Hanoi and Ho Chi Minh City (Labbé \& Musil, 2014). Development of new satellite cities in Vietnam on agricultural land is rapidly changing the architecture of the surrounding villages and has disrupted their water and communications networks (Leducq \& Scarwell, 2018). Vietnam's fragmented approach to housing markets and urban planning has also resulted in sub-optimal land utilisation, which exacerbates existing housing shortages and worsens land scarcity (Zhu, 2012).

\subsection{Rising public infrastructure deficits}

Investment in urban infrastructure services has not kept pace with demand and population growth in Southeast Asia's cities. Dahiya (2014) argues there has been a mismatch between rapid urban economic growth and the required investment in infrastructure and services, and environmental management. Cities depend on the effective and reliable operation of infrastructure systems to deliver energy, mobility, water, sanitation, shelter, information, 
emergency response and other critical services (Grafakos et al., 2016). The primary challenges with urban infrastructure are chronic in Southeast Asia, including: the rising demand for services; the increasing costs of services; inadequate, outdated or poorly maintained infrastructure; poorly performing institutions; congested roads and the prioritisation of cars over public transport (Sitko \& Goudswaard, 2019). The infrastructure investment deficit in Southeast Asian cities, particularly in environmental infrastructure is estimated at $\$ 100$ billion per annum (Arfanuzzaman \& Dahiya, 2019).

In both Cambodia and Vietnam, investment in public transportation, urban sanitation and urban water supply (to some extent) has not kept pace with urban growth. Cambodia's capital city, Phnom Penh, has over 2 million people but does not have an effective public transportation system or a centralised wastewater treatment facility. While Phnom Penh's water supply utility and infrastructure has a good track record of performance, the provision of sustainable and quality water supply infrastructure in other cities remains a challenge (World Bank, 2018). Similarly, Vietnam's investments in public transport infrastructure has stalled and the number of motorized vehicles (both motorbikes and cars) has increased rapidly (Leducq \& Scarwell, 2018; OECD, 2018) and traffic congestion is widespread (Chu \& Nguyen, 2017). For example, the construction of Hanoi's Metropolitan Rail Transport Project has been thwarted due to financial and technical problems (Leducq \& Scarwell, 2018). Vietnam has also not invested sufficiently in wastewater treatment and sewerage networks in tandem with the expansion of industrial areas (Le \& Ha, 2019). Furthermore, with insufficient investment in solid waste management infrastructure and services, up to 30 per cent of solid waste is not being collected regularly in Southeast Asian cities (Dahiya, 2014). Most cities in Cambodia do not have a sanitary land-fill infrastructure or any form of recycling, and weak solid waste management is undermining the drainage system (Curea, 2017).

\subsection{Increasing resources consumption and contribution of cities to climate change}

Economic growth and demographic changes in Southeast Asian cities have led to rising resources consumption. The number of middle-class people in the region is rapidly growing and is estimated to reach 3.2 billion by 2030 (UN-ESCAP, 2017). The urban population's desire for higher quality of life and growing consumption levels in Southeast Asia is one of the drivers of declining sustainability (Lehmann, 2018). Production and consumption patterns are not currently oriented towards resource efficiency and waste generation is increasing (Curea, 2017).

Industrial development linked to global supply chains are a major contributor to growing energy and water consumption in Southeast Asian cities. For example, in the industrial city of Hai Phong, Vietnam, electric power consumption was estimated to have tripled between 2013 and 2020, increasing reliance on fossil fuels with renewable energy remaining marginal, and with limited measures to ensure energy efficiency (OECD, 2016a). Resource efficiency is needed to optimise the use of natural resources (water, electricity, fuel, land, solid waste) taking into account their life-cycle, for and by specific urban stakeholders and systems (e.g. industries, buildings and transport) and for the metropolitan area as a whole (Daudey \& Matsumoto, 2017).

Rising resources consumption levels in cities is contributing substantially to climate change. Greenhouse gas emissions are low on a per capita basis in both Vietnam and Cambodia, but continue to increase exponentially with economic growth, particularly due to industrial development and land-use change. During Cambodia's recent phase of economic growth from 1998 to 2015, carbon dioxide emissions increased by over 50 per cent (Ozturk \& Al-Mulali, 2015). Cambodia's emissions growth has been driven by urbanisation, energy consumption and trade openness, particularly as urban development has not been supported by controlled sewerage or effective solid waste management (Ozturk \& Al-Mulali, 2015). In Vietnam, between 1986 and 2015, energy demand increased by around 2,746 times and carbon dioxide emissions increased from around 0.37 metric tonnes to 2.0 metric tonnes (Le et al., 2018).

\subsection{Declining liveability and increased exposure of urban residents to environmental contaminants}

Urban populations have become more exposed to air pollution and environmental contaminants in many Southeast Asian cities. In Phnom Penh, Cambodia, rapid real estate development occurring on in-filled lakes and without sufficient drainage has increased waterlogging in low-lying areas creating conditions for water-borne disease (Flower et al., 2018). Phnom Penh's recently built drainage infrastructure to manage floods only services the city centre, and the majority of urban districts remain at risk of flooding. Also, without a centralised wastewater treatment plant in Phnom Penh, much of the sludge from sceptic tanks used for wastewater discharge is dumped illegally in drainage channels and low-lying wetlands (Doyle, 2012). Ineffective management of solid waste is also contributing to unsanitary and polluted urban environments. In Cambodia, without effective municipal waste collection services, informal settlements tend to dump their solid waste (Daudey \& Matsumoto, 2017). Burning waste or burying it in pits near canals, rivers or the sea contributes to pollution, particularly near informal settlements (OECD, 2016b).

Industrial pollution loads are increasing in urban and peri-urban areas in Cambodia and Vietnam and are not being effectively managed. For example, in Phnom Penh, industrial emissions, including toxic chemicals are projected to increase significantly over the coming decade; the textile and apparel sector is generating the highest emissions and is project to increasing from 436,016 Mg in 2014 to 682,620 Mg in 2030 (San et al., 2018). In Ninh Binh province, Vietnam, the development of the Khanh Phu Industrial Zone has occurred without sufficient investment in water treatment and sewerage networks in the surrounding villages, exposing the community to water-borne diseases (Le \& $\mathrm{Ha}, 2019)$. In this area, air pollution from the factory emissions has also become a problem around the industrial zone causing respiratory diseases (Le \& Ha, 2019). In Hai Phong, Vietnam, industrial waste is also growing compared to other waste sources and industrial waste is projected to constitute 60 per cent of total waste in 2025 (OECD, 2016a).

Urban liveability has also been impacted by increased traffic congestion in Southeast Asia, particularly in the capital and megacities of Cambodia and Vietnam. Traffic congestion has reduced urban mobility and increased air pollution levels. In Phnom Penh, traffic surveys show that travel speeds along the main boulevards have decreased from an average of $22.9 \mathrm{~km} /$ hour in 2001 to an average of $14.6 \mathrm{~km} / \mathrm{hour}$ in 2012 (World Bank, 2018). In Ho Chi Minh City, the annual average PM10 level $(96 \mu \mathrm{g} / \mathrm{m} 3)$ is far above the recommended level by the World Health Organisation (20 ug/m3) (OECD, 2018). Without sufficient enforcement of traffic regulations and parking regulations, traffic conditions have become hazardous in both countries resulting in high numbers of road accidents and fatalities (OECD, 2018; World Bank, 2017). 
A decrease in urban green spaces, biodiversity and natural waterways is contributing to reduced urban liveability. Waterways have become progressively infilled and replaced by residential projects in several cities of Southeast Asia. Phnom Penh currently has around $1.1 \mathrm{~m}^{2} /$ resident of green space compared with Vancouver at around $30 \mathrm{~m}^{2} /$ resident (Lehmann, 2016). Research by Yen et al. (2016) demonstrated there is a high demand amongst the young residents of Phnom Penh for the ecological services of urban green spaces. In Vietnam, green spaces have become more fragmented as a result of urbanisation and land-use changes, resulting in a loss of the quality of ecological services, urban biodiversity and urban quality of life (Uy \& Nakagoshi, 2007). In Hanoi, the reduction in the size of five lakes due to urban development has negatively influenced the flood regime of the Red River (Phong, 2015).

\subsection{Increased vulnerability to climate change and disaster events, particularly for the urban poor}

Cities in Southeast Asia are increasingly exposed to climate change and disaster risks. The risk of urban flooding and storm surge is increasing due to the increased intensity of monsoon rains and expanded urban development in hazardous locations, particularly in coastal cities (Fuchs et al., 2011). The deterioration of natural ecosystems is further increasing vulnerability to floods, through clogging of rivers, in-filling of urban lakes, and destruction of mangrove forests and wetlands (Daudey \& Matsumoto, 2017). The urban heat island effect is increasing temperatures resulting from land use change and a reduction of urban green spaces and urban forests. For example, in Ho Chi Minh City, temperatures are projected increase by 1.2 and 1.7 degrees Celsius by 2050, with an additional warming of 0.5 degrees in newly urbanised areas (Doan \& Kusaka, 2018). Climate change coupled with the stresses from economic liberalisation are representing a 'double exposure' of ecological and urban systems and populations (Martin et al., 2019).

Southeast Asia's cities are exposed to global crisis events, such as pandemics, as they are well-connected to global trade and migration. The COVID-19 pandemic has had a significant economic and social impact on the cities of Cambodia and Vietnam. In Cambodia, at least 180 domestic factories (primarily in Phnom Penh) suspended their operations due to COVID-19, suspending the work of over 150,000 workers (Heng, 2020). In Vietnam, the pandemic affected the livelihoods of an estimated 4.6 to 10.3 million workers by June 2020 (International Labor Organisation [ILO], 2020). Informal workers have been the most impacted by COVID-19, because of their limited access to social protection (ILO, 2020). Gender bias is commonly found in Southeast Asia's cities (Sitko \& Goudswaard, 2019) and this gender bias has been worsened by COVID-19, as women are over-represented in the hardest hit sectors (ILO, 2020).

\subsection{Overall impact of these trends on the sustainability and resilience of cities in Cambodia and Vietnam}

In Southeast Asia, and particularly in Cambodia and Vietnam, rapid and unplanned urban development, an under-investment in urban infrastructure, and increasing levels of resources consumption, has culminated in the declining liveability of cities and cities having a rising contribution to climate change. These trends have also increased the exposure of urban residents to environmental contaminants and increased the vulnerability of urban residents to climate change and disaster events, particularly the urban poor. Overall these trends have resulted in a breakdown of economic, social and environmental infrastructure in urban areas. While urbanisation has had a transformative role in
Southeast Asia's economic growth story (Dahiya, 2014), the urban transition has been described as "incomplete" and "fundamentally unsustainable" (Arfanuzzaman \& Dahiya, 2019; UN-ESCAP, 2017).

\section{POLICY AND STRATEGY RESPONSES}

Recognising the need to re-orient urban development towards sustainability and resilience, Southeast Asian governments have recently established a range of policies and strategies to support sustainable urban development, as discussed below.

\subsection{Regional Strategies}

The Association of Southeast Asian Nations [ASEAN] established its Framework for Sustainable Urbanization in ASEAN in 2018, as an initiative under the Masterplan on ASEAN Connectivity 2025. This Framework defines sustainable urbanisation in broad terms as "promoting actions that enable urban areas to capture the benefits linked to large concentrations of people, while building resilience to the associated challenges" (ASEAN, 2018). The ASEAN Framework prioritises six areas:

- 'civic and social' including social cohesion, inclusive and equitable growth, culture and heritage, tourism

- 'health and well-being' including housing, healthcare, other public services

- 'security' including personal safety and security, cybersecurity

- 'quality environment' including water, waste \& sanitation, energy, and food

- 'built infrastructure' including mobility, building and construction, urban resilience

- 'industry and innovation' including entrepreneurship and innovation, trade and commerce, and education.

The Framework for Sustainable Urbanization in ASEAN is related to the ASEAN Initiative on Environmentally Sustainable Cities (AIESC) established by ASEAN Environment Ministers in 2005. AIESC is focused on "Clean Air, Clean Land and Clean Water" in cities. Furthermore, the ASEAN Smart Cities Network and ASEAN Smart Cities framework supports the Framework for Sustainable Urbanisation in ASEAN. Under each of these strategies and initiatives, the ASEAN Secretariat is supporting ongoing regional policy dialogue, capacity development and programs to achieve urban sustainability.

\subsection{Cambodia's policies and strategies}

Cambodia has provided national and sub-national guidance on urban green growth and sustainable city development. Cambodia has endorsed a National Policy for Green Growth (2013) and to guide its urban development process has established a Green City Strategic Planning Methodology (2016). Cambodia's methodology defines urban green growth as ensuring "the expansion of economic activities is conducted in a way to ensure environmental protection, appropriate levels of public health, low carbon emissions, and socially inclusive urban development". Cambodia's Green City Strategic Planning Methodology proposes a set of 40 targets under 8 urban themes (urban planning; urban vulnerability; energy; transport; built environment; manufacturing; solid waste; and public space and cultural heritage) which cities are to consider and adapt in developing their green city strategic plans.

Cambodia's capital city has established the Phnom Penh Sustainable City Plan 2018-2030, which sets out a vision that "by 2030, Phnom Penh will become a clean, green and competitive 
city offering a safe and quality lifestyle to its residents." Under this vision, Phnom Penh's goals are:

1) de-couple economic growth from environmental impacts

2) increase social inclusion, reduce poverty levels and improve urban welfare

3) provide urban resilience for all citizens to natural, climatic and other risks

4) ensure urban competitiveness and attractiveness to businesses.

Cambodia is currently developing an Environment and Natural Resources Code to update its existing environmental protection legislation. The draft Code includes provisions on environmental land use planning and guidance on strategic planning for sustainable cities (Royal Government of Cambodia, Minstry of Environment, 2017).

\subsection{Vietnam's policies and strategies}

Vietnam has provided national guidance on urban green growth and climate change action planning in its cities. Vietnam has established a National Green Growth Strategy (2012) and National Green Growth Action Plan 2014-2020, which have identified the need to ensure green growth in Vietnam's cities and urbanisation processes. Vietnam's National Action Plan to Implement the 2030 Agenda for Sustainable Development (2017) and the Green Growth Viet Nam Urban Development Plan until 2030 (2018) also provide specific guidance on sustainable and green urban development. Vietnamese cities such as Lao Cai and Hai Phong have developed specific action plans for green growth or climate change, aligned to these national policies (OECD, 2016a; Pulliat, 2019).

Vietnam's Circular on Urban Green Growth Indicators (2018) provides a national set of indicators to monitor and evaluate both urban green growth outcomes and activities. The 24 indicators cover four categories - economic sustainability, environmental sustainability, social inclusion, and institutional responsiveness and will support the generation of city-level green growth action plans (Soussan \& McGrath, 2019). Furthermore, Vietnam's Scheme for the Development of Smart Sustainable Cities 20182025, requires cities to develop their own Key Performance Indicators (KPIs) to measure and track the performance of smart sustainable cities (Soussan \& McGrath, 2019). The national government requires that cities develop KPIs in accordance with international standards, Vietnam's Circular on Urban Green Growth Indicators, and also reflect the Vietnamese conditions.

Vietnam is currently developing a Law on Urban Management and Development, to address the deficiencies in Vietnam's urban planning system and integrate concepts of sustainable development and urban green growth into its legal framework. The German agency, GIZ, has recommended the law ought to include a clear definition of 'sustainable urbanisation' that is nationally agreed, and which incorporates the concepts of 'resilient, smart and green' (Soussan \& McGrath, 2019).

\section{HARNESSING THE POTENTIAL TO ACCELERATE URBAN TRANSFORMATIONS THROUGH TRANSDISCLINARY RESEARCH}

While the urban sustainability and resilience-oriented policies and strategies outlined above have only been established recently, a large gap remains between their ambition and their implementation. Urban sustainability and resilience challenges are currently over-whelming urban systems and governance capacities (Dahiya, 2012; Daniere \& Garschagen, 2019). Based on the literature, a range of weaknesses in urban governance in the cities of Cambodia and Vietnam have been identified: limited coordination between agencies at different levels of government, across sectors and between municipalities; difficulties in raising finance for infrastructure; insufficient data collection; and insufficient community mobilisation to support urban sustainability initiatives (Dahiya, 2012; Leducq \& Scarwell, 2020; OECD, 2018; Pulliat, 2019; World Bank, 2018). In the following section, I discuss how sustainability transformations theory, including a framework for analysing urban transformative capacity, has the potential to support the transformation processes in Cambodia and Vietnam.

\subsection{Sustainability transformations theory}

Transformations theory has emerged as a central component of global political discourse on sustainable development, as well as in transdisciplinary research to address sustainability problems (Loorbach et al., 2017). Transformation theory helps to build an understanding of how sustainability transformations can be initiated and accelerated. Transdisciplinary research is evolving to support development of solutions to sustainability problems, drawing form multiple forms of expertise and more explicitly linking academic research to practical forms of knowledge (Scoones et al., 2020; Westley et al., 2011).

A transformation is not an incremental change. A transformation is a deep and sustained, non-linear systemic change, generally involving cultural, political, technological, economic, social and/or environmental processes (Linnér \& Wibeck, 2020). Transformation implies fundamental changes in structural, functional, relational and cognitive aspects of social-technicalecological systems that lead to new patterns of interactions and outcomes (Scoones et al., 2020). Transformability is the capacity to evolve to fundamentally new ways of living when existing ecological, economic and social conditions make the system untenable (Westley et al., 2011).

Transformation is considered to be as much a matter of social as technical innovation. Geels (2002) describes social-technical change as the process of shifting social-technical configurations, and reweaving elements, whereby changes in one element can trigger changes in other elements. Policies and institutions play a key role in enabling social-technical transitions or transformations, as well as infrastructures, cultural discourse and maintenance networks (Geels, 2002). Social innovations, such as new governance modes and business models, can contribute to large-scale technological change (Olsson et al., 2014). Promising social and technical innovations need to be nurtured and connected to broad institutional responses and resources (Westley et al., 2011).

Capacity, power and agency have key roles in large-scale political-economic transformations, particularly driven by social mobilisation. Scoones et al. (2020) describe how bottom-up approaches to transformations harness innovation potential through fostering human agency, values and capacities necessary to manage uncertainty, act collectively, identify and enact pathways to desired futures. Transformations often involve multiple actors from various institutions (e.g. market, government, science, civil society) and shifting power relations between different actors is inherent to any transformation process (Loorbach et al., 2017).

Adaptive governance is also highlighted by scholars as playing a central role in sustainability transformations. In particular, the importance of transparent and inclusive decision-making 
processes that are viewed as legitimate by stakeholders, are considered to be a precondition for effective adaptive governance systems to be sustained over time in the context of social and ecological uncertainty (Westley et al., 2011).

\subsection{Advancing knowledge on urban transformations through trans-disciplinary research}

New forms of transdisciplinary research are required to support urban transformations, including to understand the complexity of urban contexts and why problems persist, and support the rerouting of cities' development pathways towards sustainability and resilience (Bai et al., 2018; Frantzeskaki et al., 2018; Nevens et al., 2013). Some of the key enablers to urban transformations highlighted in research to date, include: entrepreneurial political leadership to steer urban projects (Block \& Paredis, 2013); use of systems thinking approaches to address complex challenges (Siri, 2016); strengthening urban transformative capacities, focusing on agency and institutions as critical levers of change (Wolfram, 2016; Wolfram et al., 2019).

The next phase of research will advance knowledge on urban governance capacities for sustainability transformations in Cambodia and Vietnam. Wolfram (2016) has defined urban transformative capacity as "the collective ability of stakeholders involved in urban development to conceive of, prepare for, initiate and perform path-deviant change toward sustainability within and across multiple complex systems that constitute the cities they relate to".

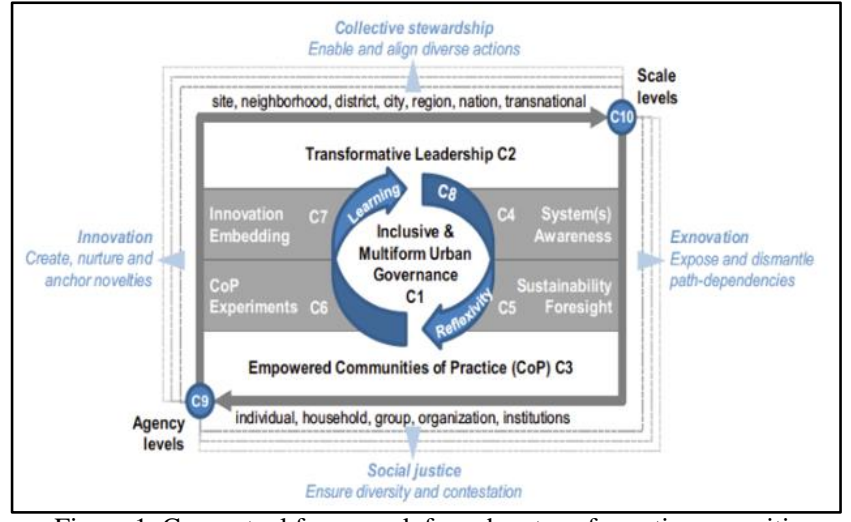

Figure 1. Conceptual framework for urban transformation capacities (Wolfram et al, 2019; Wolfram 2016-modified).

Through city-level case studies, the research will apply Wolfram's conceptual framework (figure 1) to analyse urban governance and investigate transformative capacities, such as:

- inclusive and multi-form urban governance

- transformative leadership

- empowered communities of practice

- $\quad$ systems awareness and knowledge of path dependencies

- transdisciplinary co-production of knowledge

- diverse community-based experimentation

- $\quad$ innovation embedding and coupling

- reflexivity and social learning

- working across human agency levels, politicaladministrative levels and geographical scales.

A range of urban governance stakeholders will be interviewed in the research, such as planners, utilities, municipalities, sectoral ministries, local universities, civil society, businesses, and development finance organisations. Participatory design workshops will be held involving a range of urban stakeholders in each city, to analyse institutional arrangements and potential governance improvements to achieve sustainability transformations. A cross-sectoral integrated approach will be taken in analysing the governance of urban systems, highlighting opportunities for building beneficial synergies across and within sectors and systems, such as between water, energy, food and waste, drawing on nexus approaches (Lehmann, 2018) and citylevel systems thinking (Siri, 2016). The interviews will provide empirical data on the strengths and constraints to governance for sustainability transformations from the perspectives of a diverse range of urban stakeholders in each case study city. A participatory approach enables urban stakeholders to reflect on the spectrum of factors that condition transformative change towards sustainability as set out Wolfram's framework, such as leadership, innovation, and inclusive governance.

The planned research aims to advance knowledge on how urban transformative capacities can be strengthened to overcome the sustainability and resilience challenges discussed in section two of this paper and fast-track the implementation of the policies and strategies outlined in section three. The research will help to identify and promote existing governance modes, leadership support systems, experiments and innovations that could be strengthened to achieve desired transformations. It will also identify potential constraints to adaptive urban governance, highlighting potential governance and institutional reforms in each city. The analysis of urban capacities will investigate the existing power dynamics, networks and the potential obstacles to empowerment of the urban poor and vulnerable, including political and structural obstacles. Applying a trans-disciplinary approach, knowledge will be generated through mutual learning of the researcher and participants on potential ways to strengthen governance capacities for urban sustainability transformations.

\section{ACKNOWLEDGEMENTS}

I would like to acknowledge the support provided by the Institute for Sustainable Futures, University of Technology, Sydney, which has made my $\mathrm{PhD}$ research possible.

\section{REFERENCES}

Arfanuzzaman, M., Dahiya, B. 2019. Sustainable urbanization in Southeast Asia and beyond: Challenges of population growth, land use change, and environmental health. Growth and Change, 50 (2), 725-744. https://doi.org/10.1111/grow.12297.

Association for Southeast Asian Nations [ASEAN]. 2018. Framework for Sustainable Urbanisation in ASEAN.

Bai, X., Dawson, R. J., Ürge-Vorsatz, D., Delgado, G. C., Salisu Barau, A., Dhakal, S., Dodman, D., Leonardsen, L., MassonDelmotte, V., Roberts, D. C., Schultz, S. 2018. Six research priorities for cities and climate change. Nature, 555 (7694), 2325. https://doi.org/10.1038/d41586-018-02409-z.

Bai, X., McPhearson, T., Cleugh, H., Nagendra, H., Tong, X., Zhu, T., Zhu, Y.-G. 2017. Linking Urbanization and the Environment: Conceptual and Empirical Advances. Annual Review of Environment and Resources, 42 (1), 215-240. https://doi.org/10.1146/annurev-environ-102016-061128.

Block, T., Paredis, E. 2013. Urban development projects catalyst for sustainable transformations: the need for entrepreneurial political leadership. Journal of Cleaner Production, 50, 181-188. https://doi.org/10.1016/j.jclepro.2012.11.021. 
Chu, X. N., Nguyen, V. T. 2017. Vietnamese urbanization: Actual situation and solutions for sustainable development. Advances in Natural and Applied Sciences, 11 (12), 41-48.

Curea, C. 2017. Sustainable societies and municipal solid waste management in Southeast Asia. In Sustainable Asia: Supporting the Transition to Sustainable Consumption and Production in Asian Developing Countries (pp. 391-415). World Scientific Publishing Co. https://doi.org/10.1142/9789814730914_0015.

Dahiya, B. 2012. Cities in Asia, 2012: Demographics, economics, poverty, environment and governance. Cities, 29 (Supplement 2),

https://doi.org/10.1016/j.cities.2012.06.013.

Dahiya, B. 2014. Southeast Asia and Sustainable Urbanization. Global Asia (East Asia Foundation), 9 (3), 84-91.

Daniere, A. G., Garschagen, M. 2019. Urban Climate Resilience in Southeast Asia (1st ed. 2019. ed.). Springer International Publishing. https://doi.org/10.1007/978-3-319-98968-6.

Daudey, L., Matsumoto, T. 2017. Integrating urban resilience and resource efficiency into local green growth strategies: the case of fast-growing cities in Southeast Asia. International Journal of Urban Sustainable Development, 9 (2), 226-241. https://doi.org/10.1080/19463138.2017.1339278.

Doan, V. Q., Kusaka, H. 2018. Projections of urban climate in the 2050s in a fast-growing city in Southeast Asia: The greater Ho Chi Minh City metropolitan area, Vietnam. International Journal of Climatology, 38 (11), 4155-4171. https://doi.org/10.1002/joc.5559.

Doyle, S. 2012. Phnom Penh: City of Water. Sahmakum Teang Tnaut: a Cambodian Urban NGO. www.teangtnaut.org.

Flower, B., Fortnam, M., Kol, L., Sasin, P., Wood, R. G. 2018. Using participatory methods to uncover interacting urban risks: a case study of three informal settlements in Phnom Penh, Cambodia. Environment \& Urbanization, 30 (1), 301-316. https://doi.org/10.1177/0956247817735481.

Frantzeskaki, N., Bach, M., Mguni, P. 2018. Understanding the Urban Context and Its Challenges. In Frantzeskaki, N., Hölscher, K., Bach, M., \& Avelino, F. (Eds.), Co-creating Sustainable Urban Futures: A Primer on Applying Transition Management in Cities (1st ed. 2018. ed., pp. 43-62). Springer International Publishing. https://doi.org/10.1007/978-3-319-69273-9.

Fuchs, R., Conran, M., Louis, E. 2011. Climate Change and Asia's Coastal Urban Cities: Can they Meet the Challenge? Environment and Urbanization Asia, 2 (1), 13-28. https://doi.org/10.1177/097542531000200103.

Geels, F. W. 2002. Technological transitions as evolutionary reconfiguration processes: a multi-level perspective and a casestudy. Research Policy, $31 \quad$ (8), 1257-1274. https://doi.org/10.1016/S0048-7333(02)00062-8.

Grafakos, S., Gianoli, A., Tsatsou, A. 2016. Towards the Development of an Integrated Sustainability and Resilience Benefits Assessment Framework of Urban Green Growth $\begin{array}{lllll}\text { Interventions. } & \text { Sustainability, } & 8 & \text { (5), } 461 .\end{array}$ https://doi.org/10.3390/su8050461.
Heng, K. (2020). Cambodia's COVID-19 success and economic challenges. East Asia Forum: Economics, Politics and Public Policy in East Asia and the Pacific.

Huynh, D. 2015. The misuse of urban planning in Ho Chi Minh City. Habitat International, 48, 11-19. https://doi.org/http://dx.doi.org/10.1016/j.habitatint.2015.03.007

International Labor Organisation [ILO]. 2020. Briefing Note: COVID-19 and the labour market in Vietnam. ILO, Vietnam.

Koch, F., Kabisch, S., Krellenberg, K. 2018. A Transformative Turn towards Sustainability in the Context of Urban-Related Studies? A Systematic Review from 1957 to 2016. Sustainability, 10 (1), 58. https://doi.org/10.3390/su10010058.

Labbé, D., Musil, C. 2014. Periurban Land Redevelopment in Vietnam under Market Socialism. Urban Studies, 51 (6), 11461161. https://doi.org/10.1177/0042098013495574.

Le, H., Ha, L. B. (2019). Flood Vulnerability and Resilience in Peri-urbanizing Vietnam: A Case Study from Ninh Binh Province. In Daniere, A. G. \& Garschagen, M. (Eds.), Urban Climate Resilience in Southeast Asia (1 ed., pp. 83-101). Springer International Publishing AG.

Le, H. P., Bach Van, D. T., Gia Bao, H. H. 2018. The Role of Globalization on $\mathrm{CO} 2$ Emission in Vietnam Incorporating Industrialization, Urbanization, GDP per Capita and Energy Use. International Journal of Energy Economics and Policy, 8 (6), 275-283. https://doi.org/10.32479/ijeep.7065.

Leducq, D., Scarwell, H.J. 2018. The new Hanoi: Opportunities and challenges for future urban development. Cities, 72, 70-81. https://doi.org/10.1016/j.cities.2017.08.003.

Leducq, D., Scarwell, H.J. 2020. Green-city models as an urban strategy: Hanoi between international practices and local assemblage. The Town Planning Review, 91 (4), 437-456. https://doi.org/10.3828/tpr.2020.25.

Lehmann, S. 2016. Sustainable urbanism: towards a framework for quality and optimal density? Future Cities and Environment, 2 (1), 1-13. https://doi.org/10.1186/s40984-016-0021-3.

Lehmann, S. 2018. Implementing the Urban Nexus approach for improved resource-efficiency of developing cities in SoutheastAsia. City, Culture and Society, 13 (C), 46-56. https://doi.org/10.1016/j.ccs.2017.10.003.

Linnér, B.O., Wibeck, V. 2020. Conceptualising variations in societal transformations towards sustainability. Environmental Science and Policy, 106, 221-227. https://doi.org/10.1016/j.envsci.2020.01.007.

Loorbach, D., Frantzeskaki, N., Avelino, F. 2017. Sustainability Transitions Research: Transforming Science and Practice for Societal Change. Annual Review of Environment and Resources, 42 (1), 599-626. https://doi.org/10.1146/annurev-environ102014-021340.

Martin, T., Marschke, M., Win, S. 2019. Bridging Systems and People-Centred Approaches in Urban Vulnerability Research: Insights for Resilience from Dawei, Myanmar. In Daniere, A. G. \& Garschagen, M. (Eds.), Urban Climate Resilience in Southeast Asia (1 ed., pp. 19-40). Springer International Publishing AG. 
Minnery, J., Argo, T., Winarso, H., Hau, D., Veneracion, C. C., Forbes, D., Childs, I. 2013. Slum upgrading and urban governance: Case studies in three South East Asian cities. Habitat International, $\quad 39, \quad 162$. https://doi.org/http://dx.doi.org/10.1016/j.habitatint.2012.12.002

Minstry of Environment, C. 2017. Draft Environment and Natural Resources Code, Royal Government of Cambodia.

Nevens, F., Frantzeskaki, N., Gorissen, L., Loorbach, D. 2013. Urban Transition Labs: co-creating transformative action for sustainable cities. Journal of Cleaner Production, 50, 111-122. https://doi.org/10.1016/j.jclepro.2012.12.001.

Ngo, T. T. T. 2015. Dealing with the Dragon: Urban Planning in Hanoi. In van der Veer, P. (Ed.), Handbook of Religion and the Asian City : Aspiration and Urbanization in the Twenty-First Century (pp. 186-200). University of California Press. https://doi.org/10.1525/9780520961081.

Organisation for Economic Development and Cooperation [OECD]. 2016a. Green growth in Hai Phong, Viet Nam. https://doi.org/http://dx.doi.org/10.1787/9789264260207-en.

OECD. 2016b. Urban Green Growth in Dynamic Asia. https://doi.org/10.1787/9789264266360-en.

OECD. 2018. OECD Urban Policy Reviews: Viet Nam. http://dx.doi.org/10.1787/9789264286191-en.

Olsson, P., Galaz, V., Boonstra, W. J. 2014. Sustainability transformations a resilience perspective. Ecology and Society, 19 (4). https://doi.org/10.5751/ES-06799-190401.

Ozturk, I., Al-Mulali, U. 2015. Investigating the validity of the environmental Kuznets curve hypothesis in Cambodia. $\begin{array}{llll}\text { Ecological } & \text { Indicators, } & \text { 57, } & \text { 324-330. }\end{array}$ https://doi.org/10.1016/j.ecolind.2015.05.018.

Phong, L. 2015. The Relationship Between Rivers And Cities: Influences Of Urbanization On The Riverine Zones - A Case Study Of Red River Zones In Hanoi, Vietnam. WIT Transactions on Ecology and the Environment, 193. https://doi.org/10.2495/SDP150031.

Pulliat, G. 2019. The Implementation Gap: Environmental Rhetoric Versus Reality in Lao Cai, Vietnam. Springer. https://doi.org/10.1007/978-3-319-98968-6_10.

San, V., Spoann, V., Schmidt, J. 2018. Industrial pollution load assessment in Phnom Penh, Cambodia using an industrial pollution projection system. The Science of the Total Environment, 615, 990. https://doi.org/10.1016/j.scitotenv.2017.10.006.

Scoones, I., Stirling, A., Abrol, D., Atela, J., Charli-Joseph, L., Eakin, H., Ely, A., Olsson, P., Pereira, L., Priya, R., van Zwanenberg, P., Yang, L. 2020. Transformations to sustainability: combining structural, systemic and enabling approaches. Current Opinion in Environmental Sustainability. https://doi.org/10.1016/j.cosust.2019.12.004.

Siri, J. 2016. Sustainable, healthy cities: making the most of the urban transition. Public Health Reviews, 37 (1), n/a. https://doi.org/10.1186/s40985-016-0037-0.
Sitko, P., Goudswaard, S. 2019. Development in the Urban Era: Six Strategies for Better Managing Urbanisation in Asia and the Pacfic. Research for Development Impact Network.

Soussan, J., McGrath, T. 2019. Report on Sustainable Urbanisation in Viet Nam: Recommendations to Improve the Legal Framework. Deutsche Gesellschaft für Internationale Zusammenarbeit (GIZ).

Spencer, J. H. 2010. An Emergent Landscape of Inequality in Southeast Asia: Cementing Socio-Spatial Inequalities in Viet Nam. Globalizations: Global Ideologies and Urban Landscapes, 7 (3), 431-443. https://doi.org/10.1080/14747731003669909.

United Nations Department of Economic and Social Affairs [UN-DESA]. 2018. 2018 Revision of World Urbanization Prospects.

United Nations Economic and Social Commission for the Asia and the Pacific [UN-ESCAP]. 2017. Urbanisation and sustainable development in Asia and the Pacific: linkages and policy implications, Note by the secretariat (Bangkok, 15-19 May 2017) 73rd Session. E/ESCAP/73/16.

UN-ESCAP, \& United Nations Human Settlement Programme [UN-Habitat]. 2019. The Future of Asian \& Pacific Cities: Transformative Pathways Toward Sustainable Urban Development. UN-ESCAP office, Bangkok.

UN-Habitat. 2016. World Cities Report 2016: Urbanization and Development - Emerging Futures. UN-Habitat office, Nairobi.

Uy, P., Nakagoshi, N. 2007. Analyzing urban green space pattern and eco-network in Hanoi, Vietnam. Landscape and Ecological Engineering, 3 (2), 143-157. https://doi.org/10.1007/s11355007-0030-3.

Westley, F., Olsson, P., Folke, C., Homer-Dixon, T., Vredenburg, H., Loorbach, D., Thompson, J., Nilsson, M., Lambin, E., Sendzimir, J., Banerjee, B., Galaz, V., Leeuw, S. 2011. Tipping Toward Sustainability: Emerging Pathways of

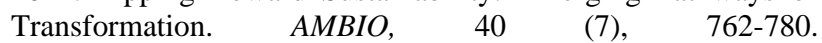
https://doi.org/10.1007/s13280-011-0186-9.

Wolfram, M. 2016. Conceptualizing urban transformative capacity: A framework for research and policy. Cities, 51, 121130. https://doi.org/10.1016/j.cities.2015.11.011.

Wolfram, M., Borgström, S., Farrelly, M. 2019. Urban transformative capacity: From concept to practice. $A M B I O, 48$ (5), 437-448. https://doi.org/10.1007/s13280-019-01169-y.

World Bank Group. 2017. Urban Development in Phnom Penh. World Bank office, Phnom Penh.

World Bank Group. 2018. Cambodia: Achieving the Potential of Urbanization. World Bank office, Phnom Penh.

Yen, Y., Wang, Z., Shi, Y., Soeung, B. 2016. An Assessment of the Knowledge and Demand of Young Residents regarding the Ecological Services of Urban Green Spaces in Phnom Penh, $\begin{array}{llll}\text { Cambodia. } & \text { Sustainability, } & 8 & \text { (6), }\end{array}$ https://doi.org/10.3390/su8060523.

Zhu, J. 2012. Development of sustainable urban forms for highdensity low-income Asian countries: The case of Vietnam. Cities, 29 (2), 77-87. https://doi.org/10.1016/j.cities.2011.08.005 